Cartwright, S. F., Pay, T. W. F. \& Henderson, W. M. (1957). J. gen. Microbiol. $16,730-748$

\title{
Multiplication of the Virus of Foot-and-Mouth Disease in Gulture
}

\author{
By SHEILA F. CARTWRIGHT, T. W. F. PAY \\ AND W. M. HENDERSON* \\ Research Institute (Animal Virus Diseases), Pirbright, Surrey
}

\begin{abstract}
SUMMARY: The infectivity curve of the virus of foot-and-mouth disease was studied in cultures of suspended trypsinized cattle-tongue epithelial cells. By this technique a known number of cells could be exposed to a known amount of virus. The pattern of multiplication was that adsorption of the virus by the cells occurred rapidly and, except with low concentrations of virus, was complete in 15-30 min. A latent period of about $2.5 \mathrm{hr}$. followed during which the virus was closely associated with the cells, was protected from the neutralizing action of antiserum, was not readily extractable but retained its infectivity. At the end of the latent period the infected cells became producers of virus at a rate estimated to be between $10^{2}$ and $10^{3} \mathrm{ID} \mathrm{50/15} \mathrm{min}$. At about $12 \mathrm{hr}$. the infectivity of the culture began to decline because of death of virus-producing cells and thermal inactivation of the virus.
\end{abstract}

The in vitro cultivation of a virus in isolated tissue offers many advantages for studying its multiplication compared with attempts to do so in an infected host. Maitland \& Maitland (1931) and Hecke (1930, 1931) reported the successful in vitro cultivation of the virus of foot-and-mouth disease in guinea-pig embryo tissue. Frenkel $(1947,1953)$ developed this culture method for routine vaccine production with epithelial tissue of cattle tongue. A variety of methods of cultivation have been studied at this Institute for virus production, for studying virus multiplication and for the development of methods of virus titration. The present paper gives the results of virus multiplication studies with culture of suspended trypsinized cattle-tongue epithelial cells. This was a development of preliminary studies of the multiplication of this virus in suspended fragments of tongue epithelium. The curves obtained as a result of infectivity titrations of tissue fragments and of the culture liquid were described by a number of workers (Henderson, 1953 $a, b$; Brooksby \& Wardle, 1954; Mackowiak, Girard, Camand \& Hirtz, 1955; Ubertini, Nardelli, Barei \& Santero, 1956). There is agreement about their general form but modifications in method were obviously necessary before a more detailed examination could be made. The techniques described in this paper, by means of which a known number of epithelial cells were exposed to a known amount of virus, were evolved for this purpose. For ease of description, it is convenient to identify the following portions of the infectivity curve; namely, the adsorption period, the latent period, the period of increasing infectivity, the period of decreasing infectivity.

* Present address: Pan American Foot-and-Mouth Disease Center, Caixa Postal 589, Rio de Janeiro, Brazil. 


\section{ME'THODS}

Foot-and-mouth disease virus. Strain Ven 1, Vallée O type. This strain was recovered from material received from an outbreak of the disease at Villa de Cura, Venezuela, in June 1950. Cultivation was begun with virus of the 2nd cattle passage in 1950; this line has since been maintained solely in culture.

Foot-and-mouth disease antiserum. Antiserum was collected from cattle or from guinea-pigs hyperimmunized with strain Ven 1 virus. The potency of the serum was determined by neutralization tests in unweaned mice (Skinner, 1953).

Preparation of tissue. Epithelial tissue was collected in strips from the tongues of recently slaughtered cattle by means of a meat-slicing machine. For routine passaging and preparation of seed virus for experiment, these strips of tissue were clipped with scissors into fragments about $5 \mathrm{~mm}$. square. The tissue was used within 3 days of collection, being stored in the interim at $4^{\circ}$ in Tyrode solution.

Trypsinized cell suspensions were prepared from strips of tongue epithelial tissue by digestion in a $0.5 \%(\mathrm{w} / \mathrm{v})$ solution of trypsin (1/250; Difco Laboratories, Detroit, Michigan) in a modified Tyrode solution free from $\mathrm{Ca}$ and $\mathbf{M g}$ (Rinaldini, 1954; $\mathrm{pH} 7 \cdot 6$ ) for up to $2 \mathrm{hr}$. at $37^{\circ}$. The tissue was stirred throughout this incubation. The undigested tissue and large clumps of cells were allowed to sediment and the supernatant cell suspension pipetted off into weighed bottles, centrifuged and the supernatant discarded. The deposit was resuspended in normal bovine serum and held for 10-15 min. at $37^{\circ}$ to allow the antitryptic action of the serum to operate. This suspension was then centrifuged, the supernatant discarded, the bottle weighed and the deposit resuspended with culture medium to a concentration of $10 \%(\mathrm{w} / \mathrm{v})$. Cell counts were made of this final suspension by mixing with an equal volume of $2 \%$ eosin in Tyrode solution and using a standard haemocytometer chamber. Ability to stain with eosin was taken as an indication that an epithelial cell was non-viable (Schrek, 1936).

Culture media. For routine passaging the medium used was Tyrode solution $+10 \%(\mathrm{v} / \mathrm{v})$ bovine serum or + the amino acids suggested by Frenkel (sec Girard \& Mackowiak, 1953). Bovine amniotic fluid or Tyrode solution + 0.5\% $(\mathrm{w} / \mathrm{v})$ lactalbumin hydrolysate (Nutritional Biochemicals Corporation, Cleveland, Ohio) was used for cell suspension cultures, this latter medium being employed for all cultures demanding only survival of suspended cells. All media had added to them $200 \mu \mathrm{g}$. dihydrostreptomycin sulphate $/ \mathrm{ml}$. 200 units benzylpenicillin (sodium salt) $/ \mathrm{ml}$. and $0.001 \%(\mathrm{w} / \mathrm{v})$ phenol red. Since the year 1955, 20 units 'Mycostatin' (E. R. Squibb and Sons, London and New York) $/ \mathrm{ml}$. have been added to control the growth of yeast contaminants when the culture was to be incubated for longer than about $12 \mathrm{hr}$. (Wigmore \& Henderson, 1955). The above media were found to be more satisfactory for survival of cells and multiplications of virus than Tyrode solution; Tyrode solution $+1 \%(\mathrm{v} / \mathrm{v})$ solution of protein hydrolysate (veterinary; Wellcome Research Laboratories, Beckenham, Kent), glucosol phosphate solution or Simm's Z16 solution (Parshley \& Simms, 1950). 
Glassware. With epithelial cell suspension cultures difficulty was experienced initially because the cells stick to the glass of culture bottles. This was intensified by the use of silicones but was effectively minimized by coating the glass with paraffin wax (m.p. $56^{\circ}$ ). The wax was removed after the bottles had been used by rinsing with hot water. Glassware used in preparing cell suspensions goes through a special procedure used at this Institute for tissue culture glassware; namely, soaking in $10 \%(\mathrm{v} / \mathrm{v})$ hydrochloric acid if tissue debris cannot be removed by brushing, rinsing in tap water, autoclaving in tap water + 'Calgon' water softener (Albright and Wilson, Ltd., London) $+0 \cdot 1 \%$ (w/v) sodium lauryl sulphate ('Empicol LZ' powder. Marchon Products Ltd., Whitehaven, Cumberland), rinsing in tap water, rinsing in distilled water, autoclaving in distilled water, rinsing in double-distilled or de-ionized distilled water and sterilizing in the autoclave or hot air oven (Sellers, unpublished work). Glassware used in routine passaging of the virus, preparation of dilutions, etc., is dealt with by standard laboratory methods.

Culture methods. Seed virus filtrates are prepared from suspensions of ground tissue in equal parts $\mathrm{M} / \mathbf{2 5}$ phosphate buffer solution and Hartley's digest broth $(\mathrm{pH} \mathrm{7 \cdot 6)}$ using filter pads of Seitz EK porosity.

For routine passaging the method used was a modification of that described by Frenkel (1947). Clipped tongue epithelium was added to the seed virus filtrate and stored at $4^{\circ}$ for not less than $1 \mathrm{hr}$. The tissue was then added to $50 \mathrm{ml}$. volumes of medium in $725 \mathrm{ml}$. flasks. The air in the flask was replaced with a mixture of $95 \%(\mathrm{v} / \mathrm{v})$ oxygen $+5 \%(\mathrm{v} / \mathrm{v})$ carbon dioxide and the flask sealed. These flasks were incubated at $37^{\circ}$ for $18-24 \mathrm{hr}$., being gently rocked during this time. This was the method used in the preliminary studies of the multiplication of the virus of foot-and-mouth disease in culture except that the tissue was washed before it was added to the culture medium by repeated centrifugation in Tyrode solution (Henderson, 1953 $a, b$ ).

The technique used for cell suspension cultures was designed to obtain as complete removal as possible of excess seed virus, the presence of which had been found to obscure initial increases in the virus content of samples of tissue and liquid. Equal parts of a $10 \%(\mathrm{w} / \mathrm{v})$ suspension of cells and seed virus filtrate were mixed at $37^{\circ}$ for $1 \mathrm{hr}$. either in a rotating bottle or preferably, to avoid packing of cells, by a magnetic stirrer. This suspension was then centrifuged at low speed and the supernatant discarded. The deposit was resuspended in Tyrode solution, centrifuged and the supernatant discarded. The deposit was then resuspended in strain-specific immune serum, left for 5 min., centrifuged and the supernatant discarded. The deposit was again resuspended in Tyrode solution, centrifuged and the supernatant discarded. This washing procedure was repeated 4 or 5 times. The deposit was finally resuspended in culture medium to the original volume to give a $10 \%(\mathrm{w} / \mathrm{v})$ concentration of cells. A cell count was made at this stage to check for losses during washing, for which adjustment was made.

Cultures were either made in multiples of 5 or $10 \mathrm{ml}$. volumes in $30 \mathrm{ml}$. screw-capped bottles, or one culture of up to $100 \mathrm{ml}$. in a $250 \mathrm{ml}$. bottle was used, with repeated withdrawal of samples. The air in the bottles was replaced 
before incubation with a mixture of $95 \%(\mathrm{v} / \mathrm{v})$ oxygen $+5 \%(\mathrm{v} / \mathrm{v})$ carbon dioxide. During incubation the bottles were slowly rotated at an angle of $10-20^{\circ}$ from the horizontal. From the time of mixing the seed virus filtrate with the cell suspension, the work was done in a hot room at $37^{\circ}$. The filtrate, cell suspension, culture medium, immune serum and the washing liquids were brought to $37^{\circ}$ before use.

\section{Preparation of infective material and estimation of its virus content}

Six different preparations have been made. The culture-liquid sample was collected from the supernatant fluid following sedimentation of the cells in a horizontal bench centrifuge. The deposit of cells was ground with sand or coarse glass powder, resuspended in $\mathrm{M} / 25$ phosphate buffer solution ( $\mathrm{pH} \mathrm{7 \cdot 6}$ ), centrifuged and the supernatant collected as the phosphate extract. The deposit of ground cells was sometimes resuspended in buffer solution and titrated without further centrifugation. The whole culture was titrated in two ways, first by making dilutions of the intact cells, suspended in the culture liquid, and secondly by depositing the cells, grinding them and resuspending them in their supernatant culture liquid. Finally the deposited cells after grinding were resuspended in antiserum, washed 4 times by repeated centrifugation and resuspended in buffer solution. Tenfold dilution series are

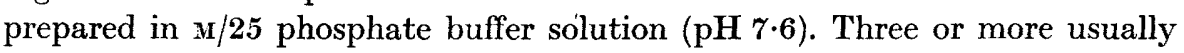
four dilutions were inoculated intraperitoneally into groups of five unweaned mice, using a $0.03 \mathrm{ml}$. dose (Skinner, 1951). The $50 \%$ end-point dilution was calculated by the method of Reed \& Muench (1938) and the virus content expressed in ID 50/g. tissue or /ml. liquid. Calculation by Pizzi's method (1950) of the standard errors of the results of these titrations gave values of the order of $\pm \mathbf{0} \cdot 35$. In comparing the results of individual titrations, therefore, the smallest significant difference was unlikely to be less than $1 \log$ unit. In all experiments to be described the necessary titration inoculations were made immediately after the collection and preparation of a sample had been completed. The interval between sampling by one worker was, because of this, never reduced to less than $15 \mathrm{~min}$.

\section{RESULTS}

Preliminary investigations with fragments of tissue exposed to virus before incubation had shown that, following an initial drop in infectivity, the virus content of the tissue began to increase $c .3 \mathrm{hr}$. after incubation. The virus titre continued to rise for the next 1-3 hr., presumably by multiplication of virus in the cells initially infected. It seemed probable that by release of this virus, other susceptible cells became infected and by a series of such steps the maximum infectivity of the culture was reached between 12 and $24 \mathrm{hr}$. (Henderson, 1953 $a, b$ ). A similar curve of multiplication was obtained when the culture of suspended tissue fragments was inoculated with the seed virus at the beginning of incubation, except that the initial decrease and increase in infectivity occurred about $\mathrm{I} \mathrm{hr}$. later. In all these experiments the presence 
of the unutilized excess of seed virus obscured the first few hours of the growth curve until sufficient production of new virus had occurred to exceed this high basal value. The use of strain-specific immune serum in cell suspension cultures as described under culture methods became the standard way of dealing with this problem. The observations which led to the adoption of this method were made, however, by using tissue fragments.

Addition of immune serum to the culture medium. The addition of immune serum at $0 \mathrm{hr}$. (Henderson, $\mathbf{1 9 5 3} a$ ) or at $\mathbf{3 0} \mathrm{min}$. produced a parallel infectivity curve about $2 \log$ units lower than that shown by control cultures without serum. When the serum was added at $2-5 \mathrm{hr}$. there was, at first, a decrease in the infectivity of the tissue, but the value subsequently achieved was the same as that in the control culture (Fig. 1). From this it was concluded that by $2 \mathrm{hr}$. the virus concerned in multiplication could not be neutralized by immune serum, although excess seed virus was neutralized. Up to $30 \mathrm{~min}$., however, the adsorption or the cellular penetration of the virus was incomplete and some could still be reached by the serum. These results with this culture system were very similar to those reported by Henle \& Henle (1949) for influenza virus in the embryonated hen egg.

In the cell suspension culture method $1 \mathrm{hr}$. was allowed to elapse before the cells were separated from the seed virus filtrate and added to the immune serum; this manipulation and the subsequent washing took about $1 \mathrm{hr}$. This first hour for adsorption or penetration is thus the maximum permissible if the various procedures are to be completed before the occurrence of the first increase in infectivity.

\section{Counts of trypsinized cell suspensions}

The epithelial cells present in these cell suspensions can be divided into large cells and small cells. The large cells are flattened, irregular in shape with much cytoplasm, and intercellular processes may be visible on the cell membrane. These and the more elongated keratinized cells are arbitrarily classified as 'prickle' cells. The small cclls tend to be spherical, are very refractile with little but dense cytoplasm; these cells are classified as 'basal' cells.

The number of cells of each type present depends on which layers are included in the strips of tongue epithelium. The proportion of basal cells may be as high as $\mathbf{7 0 - 8 0 \%}$. These cells survived the various centrifugation and washing procedures of the culture technique much better than the prickle cells which did not appear to be of much significance in the multiplication of the virus. A typical series of cell counts made during an experiment is shown in Table 1.

A preparation consisting almost entirely of viable basal cells was prepared by incubating a cell suspension overnight in bovine amniotic fluid followed by incubation with trypsin for $1 \mathrm{hr}$. It was found that few prickle cells survived the overnight incubation and thus only fully viable basal cells were left, the dead cells being digested by the trypsin. 
Table 1. Suspended cattle-tongue epithelial cell cultures of the virus of foot-and-mouth disease

Differential counts after staining with eosin ( $\%$ of total cells)

\begin{tabular}{|c|c|c|c|c|c|c|c|}
\hline \multirow[b]{2}{*}{ Sample ... } & \multirow[b]{2}{*}{$\ldots$} & \multicolumn{2}{|c|}{ Prickle cells } & \multicolumn{2}{|c|}{ Basal cells } & \multirow{2}{*}{$\begin{array}{l}\text { Total } \\
\text { basal } \\
\text { cells }\end{array}$} & \multirow{2}{*}{$\begin{array}{c}\text { Total cell } \\
\text { count (log } \\
\text { no./ml.) }\end{array}$} \\
\hline & & Stained & Unstained & Stained & Unstained & & \\
\hline $\begin{array}{l}\text { Original } 1 / 10 \text { cell } \\
\text { suspension }\end{array}$ & & $4 \cdot 4$ & $8 \cdot 0$ & $7 \cdot 1$ & $80 \cdot 3$ & $87 \cdot 4$ & $6 \cdot 65$ \\
\hline
\end{tabular}

After washing:

(a) Virus culture 10 ID 50/cell

$\begin{array}{lllllll}2 \mathrm{hr} . & 15 \cdot 5 & 0 \cdot 1 & 20 \cdot 3 & 61 \cdot 1 & 81 \cdot 4 & 6 \cdot 79 \\ 7 \mathrm{hr} . & 20 \cdot 0 & 1 \cdot 0 & 44 \cdot 8 & 34 \cdot 2 & 79 \cdot 0 & 6 \cdot 83 \\ 9 \mathrm{hr} . & 19 \cdot 6 & 0 \cdot 1 & 58 \cdot 4 & 21 \cdot 7 & 80 \cdot 1 & 6 \cdot 77 \\ 27 \mathrm{hr} . & 20 \cdot 0 & 0 & 80 \cdot 0 & 0 & 80 \cdot 1 & 6 \cdot 82\end{array}$

(b) Control

No virus

2 hr.

$7 \mathrm{hr}$.

$9 \mathrm{hr}$.

$16 \cdot 1$

\section{$1 \cdot 2$}

$28 \cdot 9$

$38 \cdot 0$

$53 \cdot 6$

82.5

$27 \mathrm{hr}$.

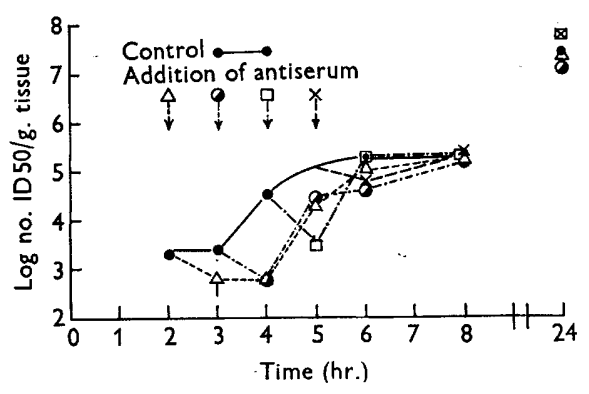

Fig. 1

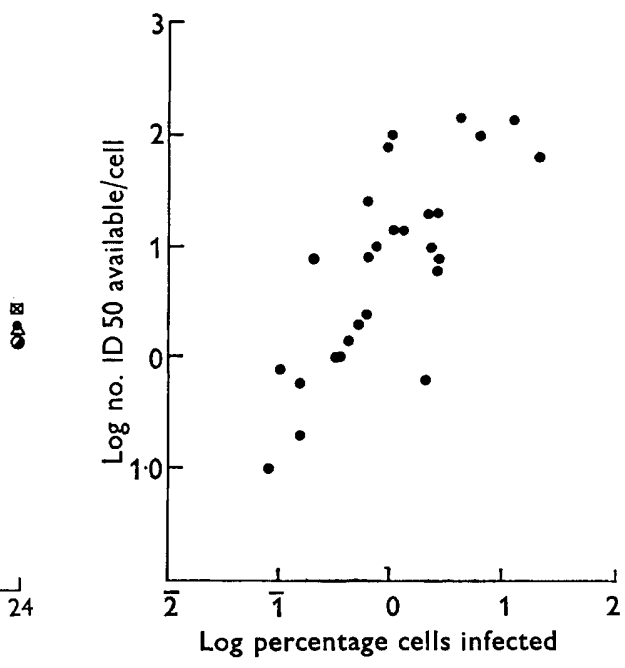

Fig. 2

Fig. 1. Effect of the addition of antiserum to cultures of the virus of foot-and-mouth disease. The infectivity is shown of the phosphate extract of the cells of the control culture and of four cultures to which serum was added at the times indicated. The $24 \mathrm{hr}$. titres are shown in the top right-hand corner.

Fig. 2. Relationship observed in 27 cultures between the amount of foot-and-mouth disease virus available to each cell and the number of cells that became infected. 


\section{The adsorption period}

Earlier work with fragments of tissue and without the use of antiserum to neutralize excess seed virus failed to show any evidence of specific adsorption of the virus by the tissue in which multiplication subsequently took place. It could only be shown that the addition of tissue to a virus suspension resulted in the tissue acquiring a virus content, the amount of which was directly proportional to the amount of virus available but was little dependent on time and temperature $\left(4^{\circ}\right.$ and $\left.37^{\circ}\right)$. When such tissue was added to a virus-free liquid, the liquid immediately acquired a virus content and the virus content of repeated washings did not greatly diminish; an equilibrium, in fact, was quickly established between tissue and liquid.

The use of antiserum and a suspension of separate cells provided new opportunities for studying the process of adsorption. Following exposure of a known number of epithelial cells to a known amount of virus and removal of excess seed virus, the cells could either be ground and a phosphate extract titrated (which provided a quantitative estimate of the infective virus content) or a titration of the cells, intact and undamaged, could be made. The latter method did not provide an estimate of the virus content but it gave an estimate of the number of infected cells. After mouse-inoculation virus multiplication proceeds in the intact infected cell with subsequent release of virus which then infects the mouse. The end-point dilution is that in which the percentage of negative samples is 50, i.e. $e^{-m}$ of the Poisson distribution $=0.5$, and $m$ the mean number of infectious units or, in this case, infected cells $=0 \cdot 7$. The number of infected cells, therefore, was 0.7 times the reciprocal of the $50 \%$ end-point dilution.

The results of titrations of the phosphate extract of cells after the use of the antiserum and subsequent washing technique showed little or no infective virus to be present. Inoculation of dilutions of the intact cells into mice, however, showed that adsorption of virus had taken place (Table 2). The question of whether this adsorbed virus then became non-infective will be examined in discussing the latent period of the infectivity curve.

The data in Table 2 show that, judging by the number of infected cells, adsorption appeared to be complete within $c$. 15-20 min. There is an indication that the rate and frequency of infection increased with an increase in the amount of virus available. During the first hour of exposure far fewer cells adsorbed virus and became infected at $4^{\circ}$ than at $37^{\circ}$, but when the period of exposure was prolonged for 4-6 hr. the degree of infection became as high as that reached at $37^{\circ}$.

Apart from these experiments in which some variation was introduced, the standard period of exposure was $1 \mathrm{hr}$. The data from twenty-seven experiments show a positive correlation between the amount of virus available and the percentage of cells that became infected (Fig. 2); these percentages are of the total number of cells. The results of differential cell counts, (Table 1) suggest that it was the basal cell that was involved in multiplication of the virus. The initial proportion of viable basal cells was usually $50-80 \%$ of the total. The 
Table 2. Exposure of known numbers of cattle-tongue epithelial cells to known amounts of foot-and-mouth disease virus for varying periods at $37^{\circ}$ and $4^{\circ}$ followed by removal of excess virus by the use of antiserum

The number of cells becoming infected was determined by dilution of the cells, intact and undamaged, and inoculation of unweaned mice.

\begin{tabular}{|c|c|c|c|c|c|}
\hline \multirow{2}{*}{$\begin{array}{c}\text { Cells } \\
(\log \text { no. } / \mathrm{ml} .)\end{array}$} & \multirow{2}{*}{$\begin{array}{c}\text { Virus } \\
(\log \text { ID 50/ml.) }\end{array}$} & \multirow[b]{2}{*}{ ID 50/cell } & \multirow{2}{*}{$\begin{array}{c}\text { Period of } \\
\text { exposure } \\
\text { (min.) }\end{array}$} & \multicolumn{2}{|c|}{$\begin{array}{l}\text { Infected cells } \\
(\log \text { no./ml. })\end{array}$} \\
\hline & & & & $37^{\circ}$ & $4^{\circ}$ \\
\hline \multirow[t]{5}{*}{$6 \cdot 6$} & $6 \cdot 4$ & 0.6 & $\mathbf{5}$ & $2 \cdot 6$ & 一 \\
\hline & & & 15 & $2 \cdot 9$ & - \\
\hline & & & 30 & $3 \cdot 8$ & - \\
\hline & & & 45 & $3 \cdot 6$ & 一 \\
\hline & & & 60 & $3 \cdot 8$ & - \\
\hline \multirow[t]{5}{*}{$6 \cdot 8$} & $7 \cdot 2$ & $\mathbf{2 \cdot 5}$ & 5 & $\mathbf{3 \cdot 9}$ & $\mathbf{2 \cdot 0}$ \\
\hline & & & 15 & $4 \cdot 6$ & $3 \cdot 0$ \\
\hline & & & 30 & $4 \cdot 8$ & $3 \cdot 0$ \\
\hline & & & 45 & $4 \cdot 8$ & $\mathbf{3} \cdot \mathbf{0}$ \\
\hline & & & 60 & $4 \cdot 6$ & $3 \cdot 0$ \\
\hline \multirow[t]{7}{*}{$6 \cdot 5$} & $7 \cdot 4$ & $8 \cdot 0$ & 15 & $\mathbf{3 \cdot 9}$ & $\mathbf{3} \cdot \mathbf{0}$ \\
\hline & & & 30 & $3 \cdot 9$ & $2 \cdot 9$ \\
\hline & & & 45 & $4 \cdot 0$ & $2 \cdot 9$ \\
\hline & & & 60 & $\mathbf{3 \cdot 8}$ & $3 \cdot 0$ \\
\hline & & & 120 & $3 \cdot 9$ & $\mathbf{2 \cdot 9}$ \\
\hline & & & 240 & $6 \cdot 4^{*}$ & $4 \cdot 1$ \\
\hline & & & 360 & $7 \cdot 2 *$ & $\mathbf{3 \cdot 9}$ \\
\hline \multirow[t]{15}{*}{$6 \cdot 7$} & $6 \cdot 6$ & 0.8 & $\mathbf{5}$ & $2 \cdot 6$ & - \\
\hline & & & 15 & $\mathbf{3} \cdot \mathbf{2}$ & - \\
\hline & & & 30 & $3 \cdot 0$ & - \\
\hline & & & 4.5 & $3 \cdot 8$ & - \\
\hline & & & 60 & $3 \cdot 8$ & - \\
\hline & $7 \cdot 6$ & $8 \cdot 0$ & $\mathbf{5}$ & $3 \cdot 8$ & - \\
\hline & & & 15 & $4 \cdot 0$ & - \\
\hline & & & 30 & $4 \cdot 4$ & - \\
\hline & & & 45 & $4 \cdot 3$ & - \\
\hline & & & 60 & 4.5 & - \\
\hline & $8 \cdot 6$ & $80 \cdot 0$ & 5 & 4.9 & - \\
\hline & & & 15 & $4 \cdot 9$ & - \\
\hline & & & 30 & $(3 \cdot 8)$ & - \\
\hline & & & 45 & $4 \cdot 8$ & - \\
\hline & & & 60 & $4 \cdot 6$ & - \\
\hline
\end{tabular}

* Increase in infectivity due to multiplication.

percentage of viable basal cells that became infected would, therefore, never have been more than twice the value shown in Fig. 2. As the proportion of cells that became infected in this system was relatively low, the absolute values are little affected and relative differences remain the same.

Titration of the seed virus filtrate during the period allowed for adsorption provided little information because of the relative insensitivity of the test except when the amount of virus available was small. Any decrease in infectivity represented more than specific adsorption by susceptible cells, since virus 'acquired' by the cells and virus adsorbed by non-viable cells is included. 
Fig. 3 shows the results obtained with three concentrations of seed virus, and it includes the amount of infectivity lost by thermal inactivation during the critical period of the experiment. It will be seen that with a low concentration of virus a decrease in infectivity might continue for 1--2 hr., this being consistent with the lower probability of collision between virus particle and cell compared with the experiments which provided the data in Table 2.

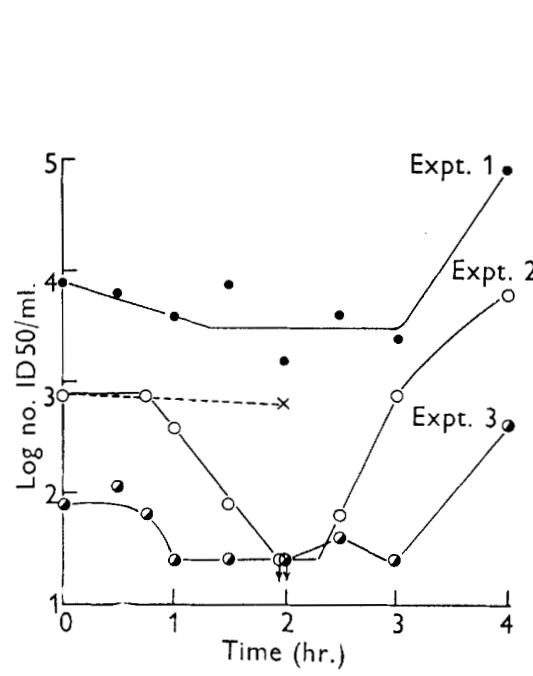

Fig. 3

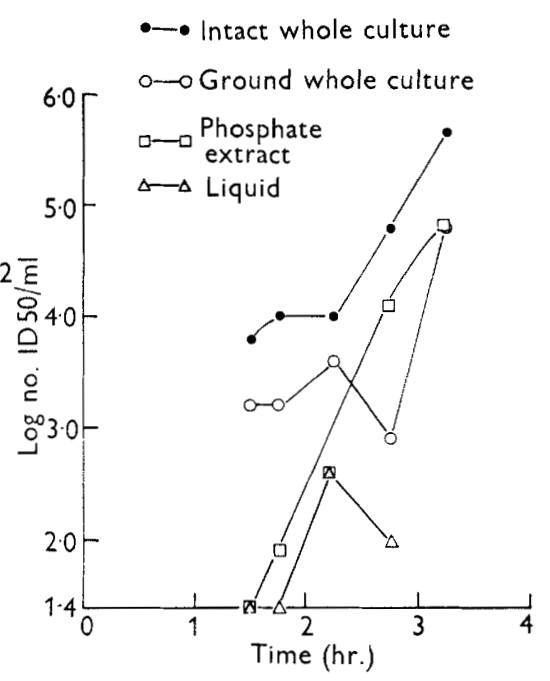

Fig. 4

Fig. 3. The virus content of the liquid portion of mixtures of virus and cells incubated at $37^{\circ}$. The low concentrations of virus used allowed the drop in infectivity due to adsorption to be detected. The dotted line shows the drop in infectivity due to thermal inactivation. The symbol $q$ denotes that no virus was detected in the undiluted preparation.

Fig. 4. The infectivity of various components of a cell suspension culture of foot-and-mouth disease virus during and immediately following the latent period.

\section{The latent period}

In identifying portions of the infectivity curve, we define the latent period as beginning with the initial decrease in infectivity when the cells are exposed to virus and ending with the increase in infectivity observed in phosphate extracts of cells which is associated with the appearance of new virus. By the methods employed, these limits cannot be exactly determined for the whole culture, far less for an individual cell + virus unit; the definition is therefore somewhat arbitrary.

In the earlier experiments there was a comparatively high virus content associated with all the components of the culture from the time it was started. An increase above this was, however, detectable after $c$. 3-4 hr. From the results of the present experiments with the use of antiserum it is evident that the high initial virus content was due to excess seed virus and that the true beginning of the increase in infectivity was not detected because of the high threshold that had to be surmounted.

In a series of four comparable experiments with ID 50 : cell ratios of 4, 19, 
13 and 8:1, respectively, samples were collected every $15 \mathrm{~min}$. starting at 1.75 hr. Phosphate extracts of the cells were prepared and titrated and dilutions of the whole culture, i.e. the intact cells in the culture medium, were also prepared and inoculated into mice. The first increase in infectivity was detected at $2 \cdot 5,2 \cdot 5,2 \cdot 25$ and $2 \cdot 25 \mathrm{hr}$. in the phosphate extract, and at 3,3 , 3.25 and $2.5 \mathrm{hr}$., respectively, in the whole culture. The two sets of times differed because titration of the phosphate extract detected any increase in infective virus in or attached to the cell whereas titration of the whole culture provided an estimate of the number of infected cells, and no increase in titre was observed so long as any increase in infective virus remained intracellular. An increase in infectivity was observed only when virus was released into the culture liquid and the amount exceeded the threshold imposed by the initial number of infected cells. The time periods cited are from the time of adding the seed virus to the cell suspension; the adsorption period was thus included. Table 2 shows that a substantial number of cells had adsorbed virus within 5 min.; it would presumably be these cells which would be associated with the first increase in virus; $\mathbf{2 \cdot 2 5 - 2 \cdot 5} \mathrm{hr}$. is therefore the approximate length of the latent period.

\section{Infectivity of the virus during the latent period}

Because of the well-recognized eclipse phase or period of non-infectivity which occurs with the multiplication of bacteriophages and with a number of animal viruses, special attention was paid to this part of the latent period in the present experiments. In searching for evidence in a cell-suspension culture the following preparations were tested: $(a)$ the culture liquid; $(b)$ the phosphate extract of the ground cells; $(c)$ the debris of the ground cells used in the preparation of $(b) ;(d)$ the intact whole culture, i.e. the undamaged cells suspended in the culture liquid; $(e)$ the ground whole culture, i.e. the cells ground and the debris resuspended in the culture liquid. A typical result is shown in Fig. 4. Iittle or no infective virus was detected in the culture liquid or in the phosphate extract of ground cells, whereas inoculation of mice with intact cells demonstrated the presence of virus which, if non-infective at the time of sampling, became infective with consequent paralysis and death of the mouse. Infective virus was also detectable in the debris of the cells used to prepare the phosphate extract.

The virus was not released during preparation of the extract in the way that it is readily extracted during the period of increasing infectivity. This demonstration of infectivity may be due to virus adsorbed by insusceptible cells not being neutralized by the antiserum, to the presence of infected cells which escaped disruption during the process of grinding, or to a proportion of virus that remained infective and intimately associated with cellular material.

These points were examined experimentally with the following results.

(1) Possibility of incomplete neutralization of non-specifically adsorbed virus. A cell suspension was prepared and a portion heated for $10 \mathrm{~min}$. at $65^{\circ}$. The heated cells were stainable with eosin. Heated and unheated cells were separately mixed with virus for $1 \mathrm{hr}$. at $37^{\circ}$, washed in the routine manner, 
using antiserum, and resuspended in culture medium. At $2 \mathrm{hr}$. titrations were made of the intact cells. No infectivity was detected in the heated cellpreparation, whereas the other contained $10^{2 \cdot 6}$ infected cells $/ \mathrm{ml}$.

(2) Possibility of infected cells surviving grinding. Microscopical examination of smears of cellular debris showed that grinding could be carried to a stage where the presence of an undamaged cell was sufficiently rare to be discounted as a possible explanation. Other methods of disruption were tried but none replaced grinding for these cells. For example, rapid freezing in solid $\mathrm{CO}_{2}+$ ethanol followed by thawing in a water-bath at $37^{\circ}$ repeated 8 times, killed the cells but did not disrupt them. Slow freezing and slow thawing was no more successful. Severe changes in osmotic pressure caused the cells to be stainable with eosin but they remained intact.

(3) Possibility of intimate association of infective virus with cellular material. It was confirmed on a number of occasions that although a phosphate extract of cells sampled during the latent period contained little or no detectable virus, a comparatively high degree of infectivity was caused by the debris of the cells used to prepare these extracts. A similar degree of infectivity was found in the ground whole-culture preparations which were obviously associated with the cellular debris, in view of the low titre of parallel samples of the culture liquid. As the virus in this debris appeared to be firmly bound an attempt was made to determine whether it was exposed to the neutralizing action of antiserum. The data for the latent period in a number of experiments is given in Table 3; in each case the culture liquid contained little virus. The cellular debris had an infectivity titre of the same order as the number of infected cells. Little or none of this infective virus was extracted by $\mathrm{M} / 25$ phosphate buffer solution ( $\mathrm{pH} 7 \cdot 6$ ) and at least $10 \%$ of it was not neutralized by antiserum.

It can be concluded, therefore, that during the latent period the association between the virus and the cell is one of close union and that unless all the fractions and components of the system are examined, it might be thought that the absence of virus from tissue extracts denoted that virus was noninfective during this period.

Reference to Fig. 6, in which the effect is illustrated of varying the initial ID 50: cell ratio, shows that when all the cells in the culture were not infected by the original exposure to virus, there was a characteristic latent period associated with each subsequent batch of cells to become infected.

\section{The period of increasing infectivity}

At the end of the latent period an increase in infectivity was observed in all the components of the culture. This increase was at first associated with the cells or in the preparations derived from them. The increase in the phosphate extract, for which there is most data, has been used to define the end of the latent period. An increase in the infectivity of the culture liquid or in the phosphate extract means that more virus has been released from the cells or is extractable from the disrupted cells.

The increases of infectivity in the phosphate extract, the ground whole 
culture and in the debris treated with antiserum appeared to occur simultaneously. An increase in the infectivity of the intact whole culture and of the culture liquid may not be detected until about $30 \mathrm{~min}$. later. The result of an experiment in which the data for all these components were obtained is shown in Fig. 5. It will be seen that there was more virus in each of the intact wholeculture samples than in the corresponding samples of the culture liquid, in the

Table 3. Virus infectivity during the latent period of the multiplication of foot-and-mouth disease virus in suspended cell cultures

Demonstration in the debris of ground cells of infectivity not extracted with phosphate buffer solution and not wholely neutralized by antiserum.

\begin{tabular}{|c|c|c|c|c|c|c|}
\hline $\begin{array}{c}\text { Initial } \\
\text { ID 50/cell }\end{array}$ & $\begin{array}{l}\text { Time } \\
\text { (hr.) }\end{array}$ & $\begin{array}{l}\text { Infected } \\
\text { cells } \\
\text { (log } \\
\text { no./ml.) }\end{array}$ & $\begin{array}{l}\text { Culture } \\
\text { liquid } \\
\text { (log } \\
\text { ID 50/ml.) }\end{array}$ & $\begin{array}{c}\text { Phosphate } \\
\text { ext. } \\
\text { (log } \\
\text { ID 50/ml.) }\end{array}$ & $\begin{array}{c}\text { Cellular } \\
\text { debris } \\
(\log \\
\text { ID 50/mI.) }\end{array}$ & $\begin{array}{l}\text { Debris + } \\
\text { antiserum } \\
\quad(\log \\
\text { ID } 50 / \mathrm{ml} .)\end{array}$ \\
\hline 2 & 0.50 & $3 \cdot 3$ & - & 0 & $2 \cdot 9$ & - \\
\hline 63 & $\begin{array}{l}1 \cdot 50 \\
1 \cdot 75 \\
2 \cdot 25\end{array}$ & $\begin{array}{l}3 \cdot 6 \\
3 \cdot 8 \\
3 \cdot 8\end{array}$ & $\begin{array}{l}1 \cdot 4 \\
0 \\
2 \cdot 6\end{array}$ & $\begin{array}{l}0 \\
1 \cdot 9 \\
2 \cdot 6\end{array}$ & $\begin{array}{l}3 \cdot 2 \\
3 \cdot 2 \\
3 \cdot 6\end{array}$ & $\begin{array}{l}2 \cdot 9 \\
4 \cdot 0 \\
2 \cdot 2\end{array}$ \\
\hline 10 & $\begin{array}{l}2 \cdot 25 \\
2 \cdot 50\end{array}$ & $\begin{array}{l}4 \cdot 4 \\
4 \cdot 0\end{array}$ & - & - & $\begin{array}{l}2 \cdot 7 \\
3 \cdot 2\end{array}$ & $\begin{array}{l}3 \cdot 2 \\
2 \cdot 4\end{array}$ \\
\hline 30 & $2 \cdot 25$ & $4 \cdot 8$ & 0 & 1.9 & $4 \cdot 6$ & $2 \cdot 6$ \\
\hline 100 & $\begin{array}{l}0 \cdot 50 \\
1 \cdot 00 \\
1 \cdot 50\end{array}$ & $\begin{array}{l}4 \cdot 7 \\
3 \cdot 8 \\
3 \cdot 9\end{array}$ & $\frac{0}{0}$ & $\frac{0}{1 \cdot 4}$ & $\begin{array}{l}3 \cdot 6 \\
3 \cdot 4 \\
3 \cdot 4\end{array}$ & $\begin{array}{l}3 \cdot 6 \\
3 \cdot 6 \\
3 \cdot 0\end{array}$ \\
\hline 40 & $\begin{array}{l}0.50 \\
1 \cdot 00 \\
1 \cdot 50 \\
2 \cdot 00\end{array}$ & $\begin{array}{l}3 \cdot 8 \\
4 \cdot 4 \\
4 \cdot 4 \\
4 \cdot 2\end{array}$ & $\begin{array}{l}- \\
\overline{1 \cdot 6} \\
(3 \cdot 2)^{*}\end{array}$ & $\begin{array}{l}- \\
\overline{1 \cdot 4} \\
1 \cdot 4\end{array}$ & $\begin{array}{l}4 \cdot 6 \\
3 \cdot 9 \\
4 \cdot 8 \\
4 \cdot 5\end{array}$ & $\begin{array}{l}2 \cdot 8 \\
3 \cdot 0 \\
2 \cdot 9 \\
2 \cdot 8\end{array}$ \\
\hline 10 & $\begin{array}{l}0.50 \\
1 \cdot 00 \\
1.50\end{array}$ & $\begin{array}{l}3 \cdot 0 \\
3 \cdot 4 \\
3 \cdot 8\end{array}$ & - & $\begin{array}{l}0 \\
1 \cdot 4 \\
0\end{array}$ & $\begin{array}{l}3 \cdot 2 \\
2 \cdot 8 \\
2 \cdot 9\end{array}$ & - \\
\hline Mean & & $4 \cdot 2$ & $1 \cdot 8$ & 1.7 & $4 \cdot 1$ & $3 \cdot 3$ \\
\hline
\end{tabular}

* Excluded in calculating the mean. The value for the $2.50 \mathrm{hr}$. sample was 1.4 .

phosphate extract or in their sums. The few values available for the ground whole-culture samples, however, are similar to those for the whole culture. The greater than thousandfold increase in the infectivity of the whole culture cannot be accounted for by a corresponding increase in the number of infected cells as the initial ID 50: cell ratio of 40 would be expected to infect all the susceptible cells and the total cell count was only $10^{6 \cdot 6} / \mathrm{ml}$., as compared with the plateau of $10^{7 \cdot 9} \mathrm{ID} \mathrm{50} / \mathrm{ml}$. reached by the whole culture. It seems probable that much of the new virus was adsorbed by dead cells and cellular debris. All this would be present in the ground whole-culture preparation but would be centrifuged out of the culture liquid and the phosphate extract samples. The results of treating the deposit with antiserum show that all but a small proportion of this adsorbed virus was neutralized.

It is more difficult to account for the increase in the infectivity of the deposit treated with antiserum. It was concluded that during the latent 
period this unneutralized virus was closely associated with infected cells. Had it been reasonable to suppose that more cells had become infected following the first release of virus it might have been assumed that this was reflected in this increase in infectivity. The coincidence in the occurrence of this increase with the rise in infectivity of the other cellular components suggests that it might be related to cells becoming producers of virus. This same pattern has

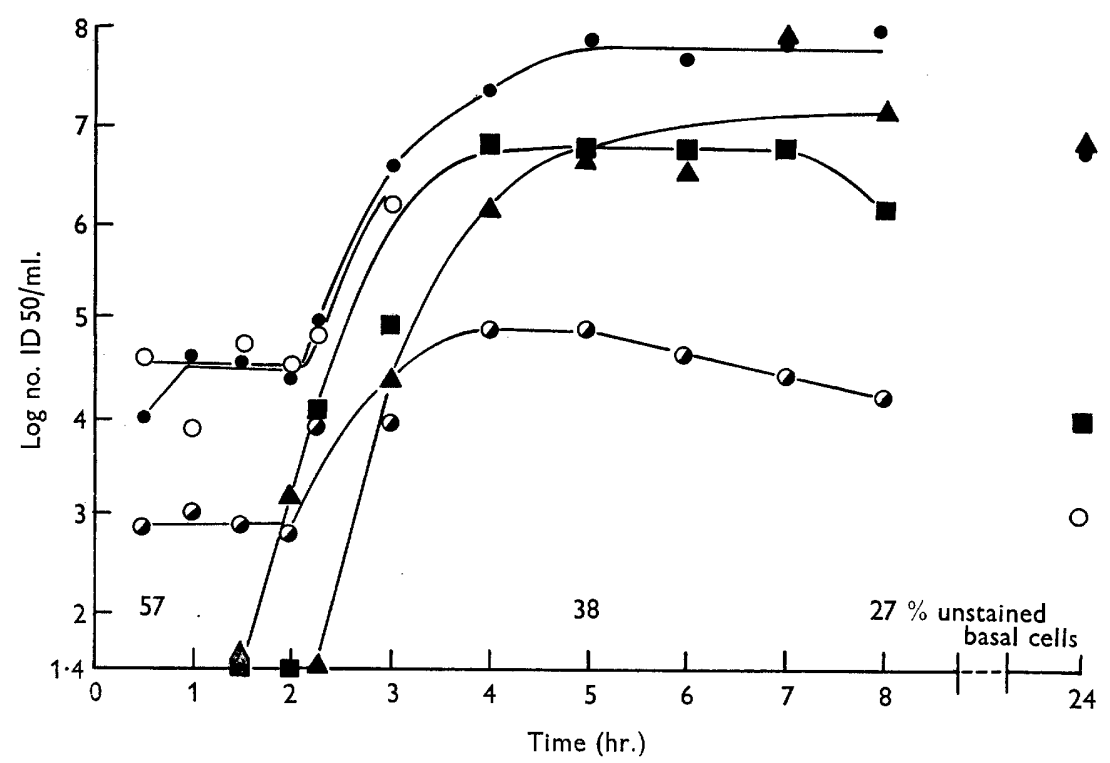

Fig. 5. The period of increasing infectivity. The preparations examined were the culture liquid $(\boldsymbol{\Delta}-\boldsymbol{\Delta})$, the phosphate extract $(\mathbf{\square}-\mathbf{\square})$, the intact whole culture $(\mathbf{0}-\mathbf{0})$, the ground whole culture $(\mathrm{O}-\mathrm{O})$ and the ground whole culture treated with antiserum $(0-0)$.

been observed in two other experiments for which complete data are available. In these, the ground whole-culture samples were titrated hourly up to $6 \mathrm{hr}$.; the results were similar to those for the intact whole culture.

There was some variation in the duration of the period of the increase in infectivity and, when judged by the virus content of the phosphate extract, its magnitude increased with an increase in the number of infected cells. The increase in infectivity was, however, comparatively constant when the number of infected cells and the peak of the first increase in infectivity attained by the whole culture were related to a unit period of $15 \mathrm{~min}$. The relevant data from fourteen experiments are given in Table 4.

The result of exposing the cells to different concentrations of seed virus is shown in Fig. 6; ID 50: cell ratios of 10:1, 1:1 and 0.1:1 were chosen. The numbers of cells which became infected were directly proportional to these values, with a tenfold difference between each. There was also a directly proportional tenfold difference between the peaks of infectivity reached following the initial infections. The three curves may be interpreted as showing that 10 ID 50/cell were sufficient for primary infection of all susceptible cells, 
but that 1 and $0 \cdot 1$ ID 50/cell were insufficient. With 1 ID 50/cell all became infected after the first release of virus, whereas it was not until there had been a release of virus from the second batch of cells which became infected that all were involved in the culture infected with $0 \cdot 1$ ID 50/cell.

Table 4. The increase in infectivity of suspended cell cultures of the virus of footand-mouth disease related to the number of infected cells, the peak of the first increase in infectivity attained by the whole culture and reduced to a unit period of $15 \mathrm{~min}$.

\begin{tabular}{|c|c|c|c|}
\hline $\begin{array}{c}\text { Infected } \\
\text { cells } \\
(\log \text { no./ml.) } \\
(a)\end{array}$ & $\begin{array}{c}\text { Peak of } \\
\text { infectivity } \\
(\log \text { ID 50/ml. }) \\
(b)\end{array}$ & $\begin{array}{l}\text { Duration of } \\
\text { 1st period of } \\
\text { increase } \\
\text { (hr.) } \\
(c)\end{array}$ & $\begin{array}{c}\frac{(b)-(a)}{(c) \div \frac{1}{4}} \\
(\log \text { ID } 50 / \\
\text { cell } / 15 \text { min.) }\end{array}$ \\
\hline $3 \cdot 05$ & $6 \cdot 0$ & 1.50 & $2 \cdot 2$ \\
\hline $3 \cdot 65$ & $6 \cdot 9$ & $2 \cdot 00$ & $2 \cdot 4$ \\
\hline $3 \cdot 85$ & $7 \cdot 0$ & $1 \cdot 00$ & $2 \cdot 6$ \\
\hline $3 \cdot 85$ & $7 \cdot 2$ & 2.00 & $2 \cdot 5$ \\
\hline 4.05 & $7 \cdot 2$ & $1 \cdot 00$ & $2 \cdot 6$ \\
\hline 4.05 & $7 \cdot 2$ & 1.75 & $\mathbf{2} \cdot \mathbf{3}$ \\
\hline $4 \cdot 25$ & $7 \cdot 8$ & 1.75 & $2 \cdot 7$ \\
\hline $4 \cdot 25$ & $7 \cdot 8$ & $2 \cdot 25$ & $2 \cdot 6$ \\
\hline $4 \cdot 45$ & $7 \cdot 9$ & $3 \cdot 00$ & $\mathbf{2} \cdot 4$ \\
\hline 4.75 & $7 \cdot 9$ & $1 \cdot 00$ & $2 \cdot 6$ \\
\hline 4.85 & $7 \cdot 0$ & 0.75 & 1.7 \\
\hline $4 \cdot 85$ & $7 \cdot 9$ & 1.75 & $\mathbf{2 \cdot 2}$ \\
\hline $5 \cdot 05$ & $8 \cdot 4$ & $1 \cdot 25$ & 2.7 \\
\hline $5 \cdot 65$ & $8 \cdot 0$ & 0.50 & 2.1 \\
\hline
\end{tabular}

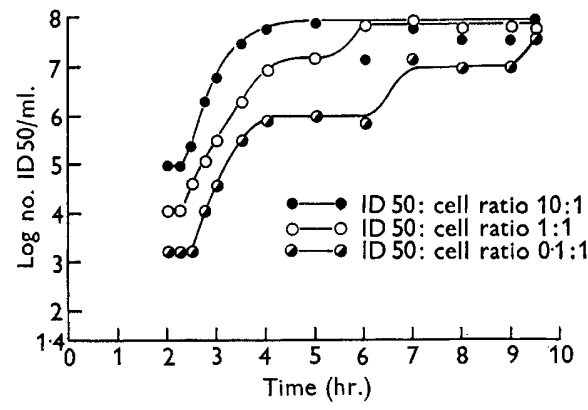

Fig. 6

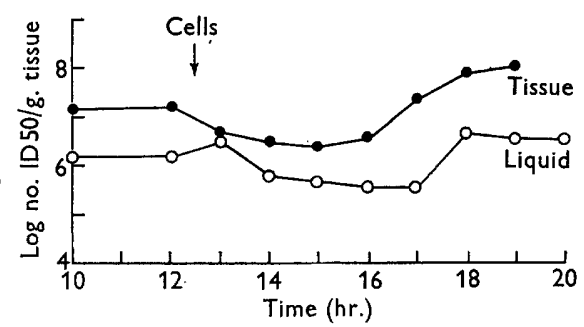

Fig. 7

Fig. 6. The infectivity of the intact whole cultures in which three virus concentrations were used.

Fig. 7 . The effect of adding susceptible cells to a culture during the period of the plateau of maximum infectivity.

A feature of these suspended cell cultures in which there was complete initial infection was that the degree of infectivity ultimately reached was maintained at a relatively constant value for about 4-6 hr. The addition of susceptible cells to the culture during this period resulted, after the appropriate latent period, in a further increase in infectivity (see Fig. 7). 


\section{Period of decreasing infectivity}

The plateau observed after the period of increase was usually maintained until between $c .10$ and $12 \mathrm{hr}$; ; thereafter there was a decrease in the infectivity of all the components of the culture. This decrease occurred more rapidly in the tissue than in the liquid. By $24 \mathrm{hr}$. the virus content of the culture was essentially that of the liquid, its degree of infectivity being about 1 log unit lower than at $12 \mathrm{hr}$. Cell counts made at $27 \mathrm{hr}$. (Table 1) showed that no viable cells remained. The decrease in infectivity appeared to be due to death of virus-producing cells, combined with thermal inactivation of the virus.

\section{DISCUSSION}

These experiments have been concerned almost entirely with the first $8 \mathrm{hr}$. of incubation of this culture system; no data are presented on any characteristic of the virus other than infectivity. The complement-fixing activity and the immunizing activity of the antigen were not detectable until the virus content of the culture exceeded $10^{5}$ or $10^{6} \mathrm{ID} 50 / \mathrm{ml}$. Ubertini et al. (1956), who studied the development of these three characteristics in cultures of cattletongue tissue fragments, only detected infectivity up to 6 or $12 \mathrm{hr}$. The method here used to determine the number of infected cells by titration of the intact whole culture during the adsorption and latent periods was based on the assumption that, since the phosphate extract was practically non-infective, 'maturation' of non-infective virus had to occur within undamaged cells after inoculation into the mouse. The fact that the most recent experiments have shown that a similar end-point is found when the ground whole culture is titrated does not invalidate the method, but it seems unnecessary to assume that any maturation is required or that cells need survive within the mouse. It must be noted that only about $1 \%$ of the total cells, as determined by the titration method, becomes infected, whereas the number of viable basal cells is usually between 70 and $80 \%$. It has been concluded, therefore, that the titration method may be accepted for the estimation of relative numbers, but not necessarily for absolute numbers, of infected cells. When, however, simultaneous titrations have been done, on a few occasions, by the plaquecounting method (Sellers, 1955) the same result has been obtained.

The production of infection by inoculation of mice with preparations of ground cells collected during the latent period provides evidence that much virus, apparently specifically adsorbed, remains infective during this period. Ackermann, Ishida \& Maassab (1955) described the occurrence of bound infectious virus in chick chorioallantoic membrane infected with influenza virus. They concluded that this bound virus did not function in the initiation of virus increase. There is some similarity with our observations on the presence of virus closely associated with the cells during the latent period, but we have no evidence that this virus should be disregarded in considering the subsequent increase in infectivity. If inoculation of a number of noninfective units or subunits of virus may be followed by their organization and 
the formation of an infective unit within the mouse, it must be recognized that this might be equally true at any time for any infective virus.

It is apparent from the literature that the search for infective virus during the latent period has not always been sufficiently exhaustive. The failure to recover infective virus from the supernatant fluid of a centrifuged suspension of ground tissue has, on occasion, been accepted as evidence of the occurrence of an eclipse phase. There is no doubt, however, that a difference existed in these experiments in the facility with which virus could be extracted or eluted from the cellular material in the later stages of its multiplication as compared with that during the latent period.

Attempts have been made with our culture system to establish the form of the differential growth curve in which the yield of virus/unit time interval is determined. The sedimentation of the cells by centrifugation for removal of the medium and during the subsequent washing procedures before new medium was added eventually killed so many cells that to do this with the necessary frequency became impracticable. The results of performing this type of experiment on monolayer cultures of bovine amniotic ectoderm (Pay, 1956) show that such cells infected with the virus of foot-and-mouth disease may release virus at a constant rate for 2-3 days. In monolayer cultures of bovinetongue epithelial cells (Pay, unpublished) the same constant release has also been observed with one type of cell-growth whereas another type of cell-growth undergoes fatal cytopathogenic changes within $24 \mathrm{hr}$. The fact that virus production ceased so much earlier in suspended-cell culture was undoubtedly due to the inability of many of these cells to remain viable in a liquid medium, whether or not they were infected, and because the remainder of the cells died, probably as a result of specific pathogenic changes.

Table 5. Increase in infectivity/15 min. in suspended cell cultures of the virus of foot-and-mouth disease in which the initial concentration of virus was 10, 1 and 0.1 ID 50/cell

\begin{tabular}{|c|c|c|c|}
\hline \multirow{2}{*}{$\begin{array}{l}\text { Time at end of } \\
15 \text { min. period } \\
\text { (hr.) }\end{array}$} & \multicolumn{3}{|c|}{ Increase in ID $50 / \mathrm{ml} . / 15 \mathrm{~min}$. } \\
\hline & Culture 10 & Culture 1 & Culture $0 \cdot 1$ \\
\hline $\mathbf{2 \cdot 2 5}$ & $\mathbf{0}$ & 0 & $\mathbf{0}$ \\
\hline $2 \cdot 50$ & 150,000 & 28,000 & $\mathbf{0}$ \\
\hline $2 \cdot 75$ & $1,750,000$ & 80,000 & 8,400 \\
\hline $3 \cdot 00$ & $4,300,000$ & 200,000 & 25,000 \\
\hline $3 \cdot 25$ & $11,700,000$ & 580,000 & 85,000 \\
\hline $3 \cdot 50$ & $14,000,000$ & $1,300,000$ & 200,000 \\
\hline 3.75 & $18,000,000$ & $2,800,000$ & 240,000 \\
\hline 4.00 & $13,000,000$ & $4,000,000$ & 240,000 \\
\hline $4 \cdot 25$ & $17,000,000$ & $3,000,000$ & 200,000 \\
\hline $4 \cdot 50$ & 0 & $3,000,000$ & $\mathbf{0}$ \\
\hline $4 \cdot 75$ & 0 & 0 & $\mathbf{0}$ \\
\hline $\begin{array}{l}\text { Mean of last } 4 \\
\text { values }\end{array}$ & $10^{7 \cdot 2}$ & $10^{6.5}$ & $10^{5 \cdot 3}$ \\
\hline $\begin{array}{l}\text { Latent period } \\
\text { titre }\end{array}$ & $10^{-5}$ & $10^{-4 \cdot 1}$ & $10^{-3 \cdot 2}$ \\
\hline Infected cells $/ \mathrm{ml}$. & $10^{4 \cdot 85}$ & $10^{3 \cdot 9}$ & $10^{3 \cdot 05}$ \\
\hline ID 50/cell/15 min. & $10^{2 \cdot 4}$ & $10^{2 \cdot 6}$ & $10^{2 \cdot 3}$ \\
\hline
\end{tabular}


Work with monolayer cultures suggests that the results of the present experiments should be interpreted on the assumption that an infected cell at the end of its latent period becomes a producer of virus, releasing it at a constant rate. Analysis of the data of the experiment illustrated in Fig. 6 shows that this hypothesis is consistent with the observations. The increase in infectivity during each $15 \mathrm{~min}$. from the end of the latent period to the first peak (Table 5) suggests that during the last four 15 min. periods a constant rate of virus production had been reached in each culture, i.e. that all infected cells were then virus producers. In the two cultures with incomplete initial infection, the infectivity would in part be due to the contribution of the number of cells in the second batch which became infected, but it can be disregarded since the maximum number available for subsequent infection was such a small proportion of the degree of infectivity attained. In the culture with an initial ID 50: cell ratio of 10:1, 10 4.85 infected cells $/ \mathrm{ml}$. had an average production of $10^{7.2} \mathrm{ID} 50 / \mathrm{ml}$. during each of the later $15 \mathrm{~min}$. periods, i.e. $10^{2.4}$ ID 50/cell/15 min. The corresponding values are $10^{2.6}$ and $10^{2.3}$ for the $1: 1$ and $0 \cdot 1: 1$ cultures, respectively. If these figures be assumed to represent the rate of virus production by an infected cell, the number of virus-producers in action during the earlier $15 \mathrm{~min}$. periods may be calculated from the total amount of virus produced during each period; the results of these calculations are given in Table 6. A similar analysis of the data of the experiment illustrated in Fig. 5 gives a virus production figure of $10^{2.9}$ ID 50/cell/15 min.

Table 6. Percentage numbers of infected cells which became virus producers during the period of increasing infectivity as calculated from the data in Table 5

Time at end of
15 min. period
(hr.)
$2 \cdot 25$
$2 \cdot 50$
$2 \cdot 75$
$3 \cdot 00$
$3 \cdot 25$
$3 \cdot 50$
$3 \cdot 75$

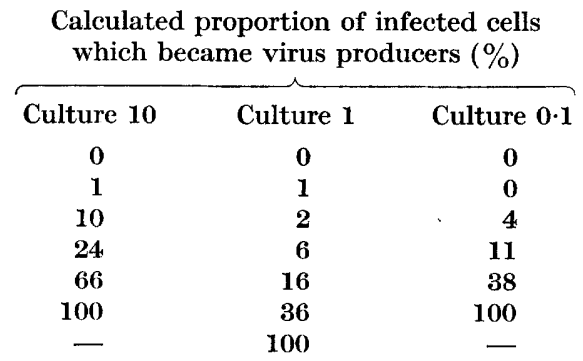

The values in Table 4, in which the total increase in infectivity is related to a 15 min. period, are underestimates of the mean virus production/cell. They would be correct only if all the cells were producing virus for the duration of the period of increase. No account is taken of the hypothesis that the number of cells which produce virus gradually increases throughout the first 60-75 min. Comparison of values obtained for $15 \mathrm{~min}$. periods from the same data by the two methods of calculation suggest that the values shown in Table 4 are underestimates by about $\mathbf{0} \cdot \mathbf{4} \log$ unit; the mean corrected value for these data is $10^{2.9}$. The conclusion reached is that the rate of virus production/cell/15 min. is probably of the order of $10^{2}$ to $10^{3} \mathrm{ID} 50$. 
Assessment of the significance of the plateau at the end of the period of increase in infectivity is complicated by the fact that at this high value an absolute increase in amount of virus must be very considerable before it can be detected. In the experiment illustrated in Fig. 6 a peak of $10^{8} \mathrm{ID50} / \mathrm{ml}$. was reached in the 10:1 culture. The estimated production attained by this time was estimated to be $10^{7.2} \mathrm{ID} 50 / 15 \mathrm{~min}$. This rate of production would have to continue for $1.75 \mathrm{hr}$. before a twofold increase had occurred, an amount not detectable by the titration method used. It is hardly possible, therefore, to conclude whether the plateau is apparent or real. The influence of thermal inactivation must be considered; a plateau would be maintained so long as thermal inactivation balanced new production. Death of infected cells would lead to a disturbance of this balance and result in the decrease of infectivity observed later. In the experiment illustrated in Fig. 5 a decrease occurred in the infectivity of the ground cells treated with antiserum and in the number of viable basal cells, while the plateau was still present. This suggests that death of infected cells might have taken place before any decrease in infectivity was large enough to be observed.

The conclusions reached are that in the described culture system the pattern of multiplication of the virus of foot-and-mouth disease was that adsorption of the virus by the cells occurred rapidly and, except with low concentrations of virus, was complete in 15-30 min. The virus then became closely associated with the cells and was not neutralized by antiserum, nor readily extractable, but retained infectivity. This state persisted during a latent period of about $2 \cdot 5 \mathrm{hr}$. At the end of this period some of the epithelial cells produced new virus at a steady rate of about $10^{2}$ to $10^{3} \mathrm{ID50/15}$ min. and all the infected cells were producing within $c .1 \mathrm{hr}$. This production continued so long as these cells survived; thereafter the infectivity of the culture declined, ultimately, because of thermal inactivation of virus. In this culture system this decline started after $c .12 \mathrm{hr}$.

We are deeply indebted for technical assistance to Miss D. M. Tucker, Miss M. E. Bissett and Mr W. J. Brownsea.

\section{REFERENCES}

Ackermani, W. W., Ishida, N. \& MaAssab, H. F. (1955). Growth characteristics of influenza virus concerning the binding of virus by host cells. J. exp. Med. 102, $54 \tilde{5}$.

Brooksby, J. B. \& Wardee, E. (1954). 'Titration of the virus of foot-and-mouth disease in culture. J. Hyg., Camb. 52, 87.

Frenkel, H. S. (1947). La culture du virus de la fièvre aphteuse sur l'epithélium de la langue des bovidés. Bull. Off. int. Epiz. 28, 155.

Frenkel, H. S. (1953). Research on foot-and-mouth disease; the cultivation of the virus on a practical scale in explanations of bovine tongue epithelium. Bull. Off. int. Epiz. 39, 91.

Girard, H. \& Mackowiak, C. (1953). La culture du virus aphteux au stade industriel. Rev. Immunol. 17, 224.

Hecke, F. (1930). Züchtungversuche des Maul- und Klauenseuchevirus in Gewebekulturen. Zbl. Bakt. (Abt. 1 Orig.), 116, 386. 
HECKE, F. (1931). Weitere Mitteilungen über die künstliche Vermehrung des Maul- und Klauenseuchevirus in Gewebekulturen. Zbl. Bakt. (Abt. 1 Orig.), $119,385$.

Henderson, W. M. (1953a). In The Nature of Virus Multiplication. Symp. Soc. Gen. Microbiol. $2,317$.

Henderson, W. M. (1953b). The use of virus culture in foot-and-mouth disease research. Proc. 15th Int. vet. Congr. Part 1, p. 191.

Henle, W. \& Henle, G. (1949). Studies on host-virus interactions in the chick embryo-influenza virus system. III. Development of infectivity, haemagglutination, and complement fixation activities during the first infectious cycle. J. exp. Med. 90, 23.

Mackowiak, C., Girard, H., Camand, R. \& Hirtz, J. (1955). Recherches sur la multiplication du virus aphteux en culture de tissu. I. Etude biologique des cultures de longe durée. Rev. Immunol. 19, 426.

Maitland, M. C. \& Mairland, H. B. (1931). Cultivation of foot-and-mouth disease virus. 4th Rep. Foot-and-Mouth Dis. Comm. London: H.M. Stationery Office.

Parshley, M. S. \& Simms, H. S. (1950). Cultivation of adult skin epithelial cells (chicken and human) in vitro. Amer. J. Anat. 86, 163.

PAY, T. W. F. (1956). Growth of bovine amniotic ectoderm as a cell monolayer on glass and its use as a system for virus multiplication. Nature, Lond. 177, 752.

Przzr, M. (1950). Sampling variation of the fifty per cent end-point, determined by the Reed-Muench (Behrens) method. Hum. Biol. 22, 151.

ReEd, L. T. \& MUench, H. (1938). A simple method of estimating fifty per cent end points. Amer. J. Hyg. 27, 493.

Rinaldini, L. M. (1954). A quantitative method of cell culture. J. Physiol. 123, $20 P$.

Schrek, R. (1936). A method for counting the viable cells in normal and in malignant cell suspensions. Amer. J. Cancer, 28, 389.

SELLERS, R. F. (1955). Growth and titration of the viruses of foot-and-mouth disease and vesicular stomatitis in kidney monolayer tissue cultures. Nature, Lond. 176, 547.

Skinner, H. H. (1951). Propagation of strains of foot-and-mouth disease virus in unweaned white mice. Proc. roy. Soc. Med. 44, 1041.

Skinner, H. H. (1953). One week old white mice as test animals in foot-and-mouth disease research. Proc. 15th Int. vet. Congr. Part 1, p. 195.

Ubertini, B., Nardelli, L., Barei, S. \& Santero, G. (1956). Études sur la culture in vitro du virus aphteux selon Frenkel. Zbl. Vet.-med. 3, 419.

Wigmore, J. O. \& HeNDERson, W. M. (1955). Control of yeast contamination by 'Mycostatin' in cultures of the virus of foot-and-mouth disease. Nature, Lond. 176, 516.

(Received 28 December 1956) 